\title{
PERAN DPD RI TERHADAP PEMBANGUNAN DAERAH PERBATASAN DAN TERTINGGAL DALAM ERA OTONOMI DAERAH
}

\author{
ERRY GUSMAN \\ Fakultas Hukum Universitas Muhammadiyah Sumatera Barat \\ errygusman@gmail.com
}

\begin{abstract}
The construction of border regions and disadvantaged areas is one of President Jokowi's and Vice President Jusuf Kalla's Nawacita program. Each region does not have to be exactly the same in carrying out development, differences in development need to be done in order to accommodate the characteristics and capabilities of each region. The term is asymmetric decentralization. This research itself is to support the Draft Law on the Acceleration of the Development of Disadvantaged Regions which is being drafted by the DPD RI. Although the government has issued various policies to catch up, but to realize the acceleration of underdeveloped regional development a strategic legal umbrella is needed. The formulation of the problems raised in this study are: 1) how to realize the acceleration of border area development and lag behind through meeting basic needs such as education, health, food, infrastructure? 2) how to synergize the implementation of these programs to reduce inequality between regions? This research will use normative juridical research and supported by empirical juridical research so that it will be able to see the realization of the acceleration of border area development and lagging through meeting basic needs such as education, health, food, and infrastructure are important in building regional development equality in Indonesia. To realize this, food needs to synergize the implementation of these programs to reduce inequality between regions in Indonesia.
\end{abstract}

Keywords: DPD RI, Development, Region, Border, Disadvantaged.

Abstrak: Pembangunan daerah perbatasan dan tertinggal merupakan salah satu program nawacita Presiden Jokowi dan Wakil Presiden Jusuf Kalla. Masing-masing daerah tak harus persis sama dalam melaksanakan pembangunan, perbedaan dalam pembangunan memang perlu dilakukan demi mengakomodir karakteristik dan kemampuan masing-masing wilayah. Istilahnya adalah desentralisasi asimetris. Penelitian ini sendiri untuk mendukung RUU Percepatan Pembangunan Daerah Tertinggal yang sedang digodok DPD RI. Meskipun pemerintah telah mengeluarkan berbagai kebijakan untuk mengejar ketertinggalan, namun untuk mewujudkan percepatan pembangunan daerah tertinggal diperlukan payung hukum yang strategis. Adapun rumusan masalah yang diangkat dalam penelitian ini adalah: 1) bagaimana mewujudkan percepatan Pembangunan Daerah perbatasan dan tertinggal melalui memenuhi kebutuhan dasar seperti pendidikan, kesehatan, pangan, sarana prasarana? 2) bagaimana mensinergikan pelaksanaan program-program tersebut untuk mengurangi ketimpangan antar daerah? Penelitian ini akan menggunakan penelitian yuridis normatif dan didukung penelitian yuridis empiris seingga akan bisa melihat perwujudan percepatan Pembangunan Daerah perbatasan dan tertinggal melalui memenuhi kebutuhan dasar seperti pendidikan, kesehatan, pangan, sarana prasarana merupakan hal yang penting dalam membangun pemerataan Pembangunan Daerah di Indonesia. Untuk mewujudkan hal tersebut makan perlu mensinergikan pelaksanaan program-program tersebut untuk mengurangi ketimpangan antar daerah di Indonesia.

Kata kunci: DPD RI, Pembangunan, Daerah, Perbatasan, Tertinggal. 


\section{A. Pendahuluan}

Kawasan perbatasan negara perlu dijaga. Tentu penjagaan tak cukup dengan tugu perbatasan dan teriakan slogan belaka, melainkan perlu bentuk konkret kehadiran negara di tengah masyarakat perbatasan. Presiden Jokowi berjanji untuk menghadirkan pembangunan di kawasan-kawasan terdepan Indonesia. Kesejahteraan harus dihadirkan di semua kawasan, tak terkecuali di tengah masyarakat perbatasan. Sejak dari awal, Presiden Jokowi dan Wakil Presiden Jusuf Kalla sudah mencanangkan Nawacita, yakni sembilan agenda prioritas untuk Indonesia. Nawacita harus digarap pemerintah periode 2014 sampai 2019 nanti. Ada prioritas untuk wilayah terdepan dalam Nawacita.

Poin pertama Nawacita adalah menghadirkan kembali negara di tengah warga negara. Keamanan batas negara berikut kedaulatan wilayah serta perlindungan terhadap sumber daya alam menjadi prioritas pemerintahan Jokowi-JK. Pembangunan perbatasan termuat dalam poin ketiga dari Nawacita. Di situ, Jokowi-JK menebalkan frase 'membangun Indonesia dari pinggiran'. Pembangunan tak lagi terpusat (sentralisasi) di perkotaan, melainkan harus dilakukan menyebar di seluruh pelosok (desentralisasi). Masing-masing daerah tak harus persis sama dalam melaksanakan pembangunan, perbedaan dalam pembangunan memang perlu dilakukan demi mengakomodir karakteristik dan kemampuan masing-masing wilayah. Istilahnya adalah desentralisasi asimetris. Meski begitu, otonomi semacam ini perlu dijaga supaya tetap sinergis.

"Kebijakan desentralisasi asimetris ini dimaksudkan untuk melindungi kepentingan nasional Indonesia di kawasan-kawasan perbatasan, memperkuat daya saing ekonomi Indonesia secara global, dan untuk membantu daerah-daerah yang kapasitas berpemerintahan belum cukup memadai dalam memberikan pelayanan publik," demikian petikan poin ketiga dari Nawacita. Jalan-jalan di pelosok dibangun, pos-pos perbatasan dipergagah, bandara di pulau terdepan didirikan. Misalnya, Pos Lintas Batas Negara (PLBN) Terpadu di Entikong, Kalimantan Barat. Ada pula PLBN Motaain, Atambua, Nusa Tenggara Timur. Bandara di pulau terdepan sudah dibangun, yang paling mengemuka di publik akhir-akhir ini adalah Bandara Miangas, proyek Rp 320 miliar yang rampung dan diresmikan Jokowi pada 19 Oktober 2016 lalu.

Proyek Jalan Trans Papua yang terhubung dengan tol laut, bila sudah jadi nanti, juga bisa memperkuat kawasan terdepan Indonesia. Panjangnya 4.330,07 km, menghubungkan Sorong di ujung Provinsi Papua Barat dengan Merauke yang berada di ujung Provinsi Papua, juga ujung Timur Indonesia berbatasan dengan Papua Nugini. Pengamanan perbatasan dilakukan. Pemerintah Jokowi yang berorientasi membangun negara jadi poros maritim dunia ini telah menetapkan 111 pulau kecil terdepan Indonesia, lewat Keputusan Presiden Nomor 6 Tahun 2017 Tentang Penetapan PulauPulau Kecil Terluar.

Berdasarkan data dari Kementerian Negara Pembangunan Daerah Tertinggal, dari 440 Kabupaten atau Kota di seluruh Indonesia terdapat 199 Daerah Tertinggal Selanjutnya. dari 69.955 jumlah Desa di seluruh Indonesia, 9.625 Desa diantaranya adalah Desa Tertinggal Dalam pada itu, berdasarkan data Direktorat Komunitas Adat Terpencil, Departemen Sosial, saat ini tercatat jumlah Komunitas Adat Terpencil (KAT) di Indonesia sebanyak 267.550 KAT dan 8 Daerah Rawan Konflik. Dari angkaangka tersebut jelas terlihat bahwa Jumlah Daerah Tertinggal serta KAT di tanah air kita cukup besar yang ditandai antara lain oleh rendahnya aksesibi- litas terhadap 
sentra-sentra pelayanan kesehatan, pendidikan, sanitasi, air bersih, perumahan dan pemukiman yang layak, sumber-sumber permodalan, teknologi informasi serta pasar hasil-hasil produksi komoditi primer (Djoharis Lubis, 2009).

Ssungguhnya Daerah Tertinggal memiliki sumber daya alam dan sumber daya manusia yang potensial untuk dikembangkan serta dikelola dan dapat dimanfaatkan untuk peningkatan kesejahteraan rakyat setempat ataupun sumber pendapatan Pemerintah daerah dan Pemerintah Pusat. Namun berdasarkan angka-angka BPS terlihat adanya kesenjangan tingkat kesejahteraan antara masyarakat Daerah Tertinggal dibandingkan dengan masyarakat lainnya sehingga perlu diupayakan Percepatan Peningkatan Kesejahteraan rakyat di Daerah Tertinggal tersebut (Djoharis Lubis, 2008).

Mengingat sebagian besar Pemerintah Daerah di beberapa Daerah Tertinggal memiliki keterbatasan dari segi pendanaan, teknologi, dan kualitas sumber daya manusia dan melihat berbagai upaya yang dilakukan Kementerian Negara Pembangunan Daerah Tertinggal serta Departemen teknis terkait lainnya masih memerlukan peningkatan Koordinasi, Integrasi, dan Sinkronisasi baik pada tataran kebija- kan mikro strategis, makro operasional maupun kebijakan mikro strategis dan mikro operasional dibidang kesehatan, pendidikan dan ekonomi kerakyatan serta pemecahan masalah sosial lainnya, maka dirasa perlu melaksanakan kajian atau telaahaan tentang Percepatan Peningkatan Kesejahteraan Rakyat di Daerah tertinggal.

Undang-Undang Nomor 23 Tahun 2014 tentang Pemerintahan Daerah, pengaturan tentang pengembangan kawasan perbatasan secara hukum berada di bawah tanggung jawab pemerintah daerah. Kewenangan pemerintah pusat hanya ada pada pintu-pintu perbatasan (border gate) yang meliputi aspek kepabeanan, keimigrasian, karantina, keamanan dan pertahanan (CIQS). Namun demikian, dalam pelaksanaannya kewenangan yang pemerintah daerah belum terimplementasi secara jelas. Pemerintah daerah masih menghadapi hambatan dalam mengembangkan kawasan perbatasan menjadi kawasan pertumbuhan ekonomi baru di era otonomi daerah saat ini. Salah satunya adalah karena pemerintah pusat masih cenderung mendominasi pembangunan sosial ekonomi di daerah perbatasan dengan alasan untuk mengintegrasikan berbagai kegiatan sosial ekonomi yang bersifat lintas administrasi wilayah pemerintahan sehingga diperlukan koordinasi dari institusi yang secara hirarkis lebih tinggi (RUU tentang Pengelolaan Daerah Perbatasan). Akibatnya elemen di pemerintah daerah terkesan kurang dilibatkan secara signifikan dalam formulasi dan pelaksanaan kebijakan pembangunan kawasan perbatasan.

Rancangan Undang-Undang tentang Percepatan Pembangunan Daerah Tertinggal hadir untuk mewujudkan percepatan Pembangunan Daerah perbatasan dan tertinggal melalui memenuhi kebutuhan dasar seperti pendidikan, kesehatan, pangan, sarana prasarana serta mensinergikan pelaksanaan program-program tersebut untuk mengurangi ketimpangan antar daerah di era otonomi daerah.

\section{B. Metodologi Penelitian}

Sebagaimana diketahui kata metode berasal dari kata Yunani "methods" atau dari kata latin "methodus" yang berarti upaya untuk mencari pengetahuan dan memeriksa secara rasional (atau meneliti) dan cara melakukan kegiatan penelitian (C.F.G Sunaryati Hartono, 2006). Metode penelitian pada dasarnya tidak lebih dari tiga langkah sederhana, yaitu dengan melakukan pengamatan dengan cermat, menyusun penjelasan berdasarkan temuan-temuan yang masih belum dipahami, kemudian menguji penjelasan tersebut (Stephan S Carey, 2015). Menemukan berarti berusaha 
mendapatkan sesuatu untuk mengisi kekosongan atau kekurangan. Mengembangkan berarti memperluas dan menggali dalam apa yang sudah ada, sedangkan menguji kebenaran dilakukan jika apa yang sudah ada masih atau menjadi diragukan kebenarannya (Beni Ahmad Saebani, 2009). Dalam penelitian hukum harus dilakukan dengan aktivitas-aktivitas untuk mengungkap kebenaran hukum yang dilakukan secara terencana dan metodologis, maka metode pendekatan yang digunakan dalam penelitian ini, adalah pendekatan yuridis normatif. Dengan penelitian ini merupakan penelitian deskriptif yang menggambarkan peran DPD RI terhadap pembangunan daerah perbatasan dan tertinggal dalam era otonomi daerah.

\section{Hasil dan Pembahasan}

Proses desentralisasi saat ini telah memasuki tahun terakhir tahapan instalasi yang berlangsung dari tahun 2002 sampai dengan tahun 2003. Pada tahun 2004, tahapan desentralisasi akan memasuki tahapan konsolidasi yang direncanakan berlangsung sampai dengan tahun 2007. Tantangan konsolidasi otonomi daerah adalah: (1) masih rendahnya profesionalisme aparatur pemerintahan daerah (eksekutif, legislatif, dan yudikatif) baik dalam hal manajerial dan teknis pemerintahan maupun dalam hal pelayanan kepada masyarakat dan pihak terkait lainnya serta meningkatkan kerjasama antar daerah maupun antar sektor yang dapat memperbaiki dan mengefisiensikan kegiatan pembangunan daerah; (2) masih rendahnya efisiensi dan efektivitas kinerja kelembagaan; (3) masih rendahnya kualitas proses perencanaan dan pengendalian pembangunan daerah, antar daerah, dan antara daerah dengan pusat; (4) belum sempurnanya syarat pembentukan daerah otonom baru; (5) masih rendahnya pengelolaan keuangan daerah berbasis kinerja dan kemampuan keuangan daerah; (6) masih rendahnya kemampuan daerah menarik investasi; (7) masih rendahnya kemampuan teknis anggota DPRD; dan (8) masih rendahnya pelayanan publik.

Kendala yang dihadapi adalah: (1) belum lengkapnya perangkat pelaksanaan, terutama peraturan perundang-undangan penjelasan UU Pemerintah Daerah dan belum sejalannya pengaturan kegiatan sektoral dengan semangat otonomi daerah; (2) rendahnya kualitas dan kapasitas teknis aparatur daerah; (3) belum lengkap dan memadainya sarana dan prasarana; (4) belum optimalnya partisipasi organisasi non pemerintah dan masyarakat; dan (5) masih rendahnya kemampuan pengelolaan dan kapasitas keuangan daerah dibandingkan dengan tanggung jawabnya yang semakin besar terutama untuk daerah-daerah pemekaran baru, daerah perbatasan dan daerah yang SDAnya terbatas.

Tantangan pengembangan wilayah adalah: (1) masih besarnya kesenjangan pembangunan antar daerah dan perbedaan tingkat kesejahteraan masyarakat (quality of life) antar daerah dan antar desa-kota yang diperkirakan akan semakin meningkat di era desentralisasi dan otonomi daerah apabila faktor-faktor penyebabnya tidak ditangani secara mendasar; (2) meningkatnya kemiskinan; (3) masih banyaknya daerah-daerah terisolasi; (4) menurunnya kesempatan kerja dalam berbagai sektor pembangunan wilayah; serta (5) masih belum optimalnya penanganan wilayahwilayah konflik di beberapa daerah.

Kendala utama yang dihadapi adalah: (1) rendahnya kualitas SDM; (2) lemahnya struktur kelembagaan; (3) kurangnya konsistensi dan keterpaduan program-program pembangunan maupun berbagai peraturan dan perundangan; (4) kurangnya keterlibatan masyarakat luas, terutama pihak swasta dan dunia usaha dalam keputusan 
publik dan pembangunan ekonomi wilayah; serta (5) kurang menariknya iklim investasi, khususnya yang menyangkut: (a) keterbatasan jaringan prasarana dan sarana wilayah, (b) keterbatasan akses kepada modal/kapital, dan (c) masih kurangnya insentif fiskal, khususnya di kawasan timur Indonesia.

Tantangan pengembangan wilayah strategis dan cepat tumbuh adalah: (1) masih rendahnya laju pertumbuhan kawasan-kawasan tersebut karena rendahnya investasi dalam maupun luar negeri akibat munculnya wilayah-wilayah lain di luar negeri yang menjadi pesaing wilayah strategis dan cepat tumbuh di dalam negeri sejalan dengan penerapan perjanjian perdagangan bebas seperti AFTA dan APEC.

Kendala yang dihadapi adalah: (1) keterbatasan jaringan jalan dan sarana perhubungan lainnya serta jaringan telekomunikasi yang menghubungkan wilayahwilayah strategis dan cepat tumbuh di dalam negeri dengan pusat-pusat perekonomian dunia; (2) belum optimalnya keterlibatan swasta, lembaga non pemerintah, dan masyarakat lokal dalam pembangunan kawasan; (3) minimnya informasi dan akses masyarakat di daerah terhadap modal, input produksi, teknologi, pasar, serta peluang usaha dan kerjasama investasi; serta (4) belum sinkronnya persepsi dalam pengelolaan kawasan-kawasan khusus seperti kawasan perdagangan bebas dan pelabuhan bebas yang pada akhirnya akan menimbulkan rendahnya efisiensi dan efektivitas pengembangan kawasan tersebut.

Tantangan percepatan pengembangan KTI dan wilayah tertinggal lainnya adalah: (1) masih besarnya jumlah dan sebaran lokasi wilayah tertinggal yang sebagian besar berada di KTI; (2) beragamnya tingkat ketertinggalan serta karakteristik masingmasing wilayah yang menuntut perhatian seksama dalam jangka panjang. Kendala yang dihadapi dalam upaya pengembangan wilayah tertinggal adalah: (1) belum optimal dan sinergisnya upaya-upaya percepatan pengembangan wilayah tertinggal; (2) tidak adanya kebijakan yang memprioritaskan penanganan wilayah tertinggal, baik di tingkat nasional maupun di tingkat daerah.

Tantangan utama dalam pembangunan perkotaan adalah: (1) belum terwujudnya kualitas kota yang layak huni dan belum sinerginya perkotaan- perdesaan dalam dinamika otonomi daerah dan globalisasi; (2) sulitnya mengendalikan laju pertumbuhan urbanisasi dan perkembangan kota yang meluas (urban sprawl) di kotakota besar dan metropolitan yang secara spasial menyebabkan terjadinya dominasi kota-kota besar dan metropolitan terhadap kota-kota hinterland- nya, terutama di Pulau Jawa; (3) belum optimalnya fungsi kota-kota kecil dan menengah dalam menahan laju migrasi penduduk desa ke kota-kota besar dan metropolitan sehingga mengganggu sistem hirarki kota; (4) belum terbangunnya sinergi perkotaan-perdesaan; (5) pesatnya peningkatan kebutuhan prasarana dan sarana kota terutama jaringan pengendalian banjir dan drainase; (6) masih tingginya tuntutan peningkatan kualitas pelayanan publik di kota; (7) belum efisiennya pemanfaatan lahan kota yang akan menimbulkan konflik, serta tidak diperhatikannya daya dukung lingkungan; (8) meningkatnya masalah kemiskinan dan kerawanan sosial di perkotaan; (9) menurunnya kualitas lingkungan hidup di perkotaan; serta (10) pesatnya perkembangan sektor ekonomi informal seiring dengan peningkatan jumlah angkatan kerja di perkotaan.

Kendala yang dihadapi adalah: (1) belum memadainya kapasitas pengelolaan kota (urban management); (2) tumpang tindihnya peraturan yang ada; (3) belum meluasnya pendekatan urban-rural linkages dan agropolitan untuk membangun sinergi kota-desa; (4) belum terintegrasinya pengembangan sektor ekonomi informal dalam struktur ruang kota; serta (5) terbatasnya kerjasama pembangunan antar kota dan antar daerah dalam pengembangan wilayahnya. 
Tantangan pembangunan perumahan adalah: (1) masih tingginya kebutuhan masyarakat akan rumah yang belum dapat terpenuhi yang diperkirakan mencapai sekitar 5 juta unit dengan kebutuhan baru sebanyak 800 ribu unit per tahun; (2) masih banyaknya jumlah rumah tangga yang bertempat tinggal dalam rumah dan kawasan yang tidak layak huni; dan (3) tidak tersedianya dana jangka panjang untuk pembiayaan perumahan. Kendala pembangunan perumahan adalah: (1) belum terbangunnya sistem penyelenggaraan perumahan dan permukiman; (2) belum sistematisnya pembiayaan perumahan dan pasar perumahan; (3) menurunnya kualitas lingkungan permukiman; (4) belum seimbangnya kebutuhan dengan kemampuan pemenuhannya; serta (5) belum tersedianya informasi dan wadah komunikasi dalam penyelenggaraan perumahan - permukiman bagi seluruh lapisan masyarakat.

Tantangan pembangunan permukiman adalah: (1) masih rendahnya cakupan pelayanan air minum; (2) masih tingginya tingkat kebocoran penyediaan air minum; (3) masih rendahnya proporsi penduduk kota yang mendapatkan pelayanan pengelolaan air limbah; (4) belum terpadunya penanganan drainase kota dengan pengendalian banjir dan masih luasnya wilayah tergenang di perkotaan; dan (5) masih lemahnya manajemen penanganan sampah di perkotaan. Kendala yang dihadapi adalah: (1) masih lemahnya pengaturan dan regulasi air minum dan sanitasi; (2) rendahnya kesadaran masyarakat, pemerintah dan pihak terkait lainnya akan pentingnya penanganan penyehatan lingkungan; (3) masihlemahnya manajemen PDAM; dan (4) masih kurangnya keterlibatan swasta dalam penyediaan prasarana, sarana, dan pengelolaan air minum serta penyehatan lingkungan.

Tantangan penataan ruang adalah: (1) belum terwujudnya rencana tata ruang sebagai acuan bagi pembangunan nasional dan pengembangan daerah; (2) belum dijadikannya penataan ruang sebagai usaha preventif yang penting dalam proses pelestarian SDA dan lingkungan hidup. Kendala untuk bidang penataan ruang adalah (1) kurang berjalannya mekanisme pengendalian pelaksanaan rencana yang telah mempertimbangkan seluruh aspek penting yang perlu dicapai dan ditargetkan dapat dicapai apabila rencana tersebut dilaksanakan dengan baik; (2) belum adanya mekanisme penegakan hukum bagi penyimpangan pemanfaatan ruang yang tidak sesuai dengan rencana baik yang dilakukan oleh masyarakat ataupun oleh pemerintah sendiri; (3) rendahnya pemahanan, disiplin, konsistensi dan dukungan para pihak terhadap kegiatan penataan ruang.

Tantangan bidang pengelolaan pertanahan adalah: (1) masih lemahnya jaminan kepastian hukum hak atas tanah; (2) belum tuntasnya pelaksanaan desentralisasi pertanahan karena belum sinkronnya peraturan yang ada; (3) belum teratasinya ketimpangan dan ketidakadilan dalam penguasaan dan pemilikan tanah; (4) belum teratasinya penggunaan tanah yang tidak sesuai dengan fungsinya dan pengalihan fungsi tanah beririgasi teknis menjadi tanah non-pertanian; dan (5) belum optimalnya pelayanan bidang pertanahan. Kendala yang dihadapi adalah: (1) belum lengkap dan harmonisnya peraturan perundangan-undangan pertanahan yang ada dengan peraturan bidang lainnya; (2) masih terbatasnya kapasitas daerah, baik dalam aspek peraturan daerah, kelembagaan, sumberdaya manusia, sistem informasi maupun pembiayaan, dalam memberikan pelayanan pertanahan pada masyarakat dalam rangka penyelenggaraan otonomi daerah; (3) masih adanya konsentrasi penguasaan dan pemilikan tanah oleh pihak-pihak tertentu; (4) belum memadainya kapasitas aparat pemerintah dan kurangnya partisipasi masyarakat dalam pengendalian pemanfaatan 
tanah; serta (5) masih rendahnya kinerja pelayanan pertanahan termasuk belum tertibnya administrasi pertanahan, lambatnya proses sertifikasi tanah serta besarnya proporsi bidang tanah yang belum disertifikasi.

Tantangan peningkatan penanggulangan kemiskinan adalah belum samanya persepsi dan definisi mengenai sumber-sumber permasalahan kemiskinan yang lebih spesifik. Kendala yang dihadapi adalah: (1) masih dilaksanakannya strategi yang lebih banyak bersifat subsidi, pemberian bantuan (dana, pendampingan, sarana, prasarana); (2) belum diadopsinya strategi perluasan kesempatan kerja, strategi pemberdayaan masyarakat, strategi peningkatan kapasitas, dan strategi perlindungan sosial untuk mewujudkan penanggulangan kemiskinan yang sistematik; (3) belum responsifnya kebijakan dan program yang ditempuh masing-masing Departemen/LPND dalam mengatasi masalah kemiskinan secara langsung; (4) sangat bervariasinya targeting dan belum adanya suatu mekanisme yang jelas tentang desain monitoring dan evaluasi sehingga sulit untuk mengetahui kapabilitas program yang dijalankan.

\section{Penutup}

Berdasarkan penyajian diatas maka penelitian ini akan memberikan masukan terhadap Percepatan Pembangunan Daerah Tertinggal hadir untuk mewujudkan percepatan Pembangunan Daerah perbatasan dan tertinggal melalui memenuhi kebutuhan dasar seperti pendidikan, kesehatan, pangan, sarana prasarana serta mensinergikan pelaksanaan program-program tersebut untuk mengurangi ketimpangan antar daerah di era otonomi daerah. Tujuan Percepatan Pembangunan Daerah Tertinggal intinya adalah melakukan percepatan pada terpenuhinya kebutuhan dasar yaitu pendidikan, kesehatan, lapangan pekerjaan, dan sarana prasarana di daerah tertinggal. Untuk itu dibutuhkan upaya untuk mempercepat kesejahteraan masyarakat daerah tertinggal, mengurangi ketimpangan antar daerah dan antar golongan masyarakat dan mensinergikan pelaksanaan program yang mencakup wilayah perbatasan, pedesaan, kawasan, dan pemerataan penduduk.

\section{Daftar Pustaka}

Beni Ahmad Saebani, Metode Penelitian Hukum, Pustaka Setia, Bandung, 2009.

C.F.G Sunaryati Hartono, Penelitian Hukum Di Indonesia Pada Akhir Abad Ke-20, Cetakan Kedua, Alumni, Bandung, 2006.

Djoharis Lubis, Pembangunan Daerah Tertinggal Di Era Otonomi Daerah, Forum Ilmiah Indonusa, Volume 5, Nomor 3, September 2008.

Djoharis Lubis, Kajian Telaahan Pembangunan Daerah Tertinggal Di Era Otonomi Daerah, Volume 6, Nomor 1, September 2009.

DPD RI, Rancangan Undang-Undang Tentang Pengelolaan Daerah Perbatasan, DPD RI, Jakarta, 2013.

Stephan S. Carey, A Beginner's Guide to Scientific Method, Wasworth Cengage Learning, 2004. (Penerjemah) Irfan M Zakkie, Kaidah-Kaidah Metode Ilmiah Panduan Untuk Penelitian dan Crtical Thinking, Nusamedia, Bandung, 2015. 